\title{
Clinical trials in the development of biosimilars: future considerations
}

This article was published in the following Dove Press journal:

Biosimilars

9 July 2015

Number of times this article has been viewed

\section{Brenda J Huneycutt ${ }^{\prime}$ \\ Earl Gillespie ${ }^{2}$ Gillian R Woollett'}

'FDA Regulatory Strategy and Policy, Avalere Health, LLC, Washington, DC, ${ }^{2}$ Health Advances, LLC, Weston, MA, USA

Video abstract

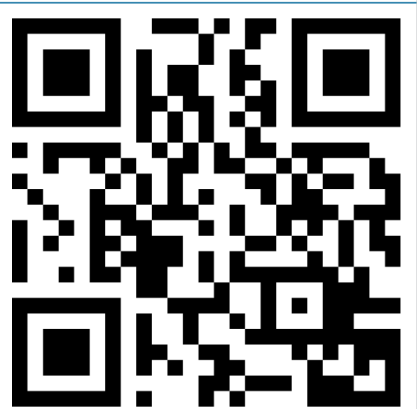

Point your SmartPhone at the code above. If you have a $Q R$ code reader the video abstract will appear. Or use: http://youtu.be/MOF7A790imo
Correspondence: Gillian R Woollett Avalere Health, LLC, I350 Connecticut Avenue, NW Suite 900,

Washington, DC 20036, USA

Tel + I 202207 I320

Fax + I 2024674455

Email gwoollett@avalere.com
Abstract: A number of biosimilars have been approved in highly regulated markets throughout the world. Biosimilar development follows its own unique path - relying primarily on analytics to compare a potential biosimilar to its reference product and giving a reduced, confirmatory role to clinical trials. In addition, the ability to extrapolate data to support approval for indications without a clinical trial gives this abbreviated pathway potential significant value. In fact, so far, all the approved biosimilars in Europe received approval for all the reference product's indications. However, this is not the case in other regions. Regulatory agencies of the highly regulated markets agree in general on many principles underlying biosimilar product development and approval, but differ in important aspects as reflected by the data burdens and approval decisions for four classes of products explored in this paper-somatropins, filgrastims, epoetins, and infliximabs. These case studies also highlight some biosimilar sponsor latitude as reflected in the varying clinical data packages submitted to the same regulatory agency for biosimilars to the same reference product. There also exists biosimilar sponsor latitude in deciding whether to use the biosimilar pathway at all or seek approval through the stand-alone biologics regulatory pathway. This, of course, is a commercial decision based on the weights each biosimilar sponsor gives to the various risks and benefits for each option, for each product, and for each market. Further, it remains an open question whether a single, biosimilar development plan for global commercialization can be used to satisfy each regulatory agency.

Keywords: somatropin, filgrastim, epoetin, infliximab

\section{Introduction}

In the 9 years since the European Medicines Agency (EMA) became the first regulatory agency to approve a biosimilar, over 20 biosimilar products have been approved in Europe, and a number of these biosimilars have also been approved as biosimilars in Australia, Japan, and/or Canada (Table 1). In the United States (US), the Food and Drug Administration (FDA) is expected to approve its first biosimilar this year. In addition, many countries outside of the highly regulated markets have approved so-called follow-on biologics, which, unlike biosimilars in the US, Japan, Australia, and Europe or subsequent entry biologics (SEBs) in Canada, are developed to copy a reference product but have not been subjected to head-to-head comparative studies with that reference product to meet the same approval standards as in the highly regulated markets. These follow-on biologics provide critical access to these medicines for patients, but should not be confused with biosimilars or SEBs or products that have undergone this rigorous testing.

Biosimilar development bears little resemblance to development pathways for either an originator biologic or a small-molecule generic drug. In general, by virtue of their low 


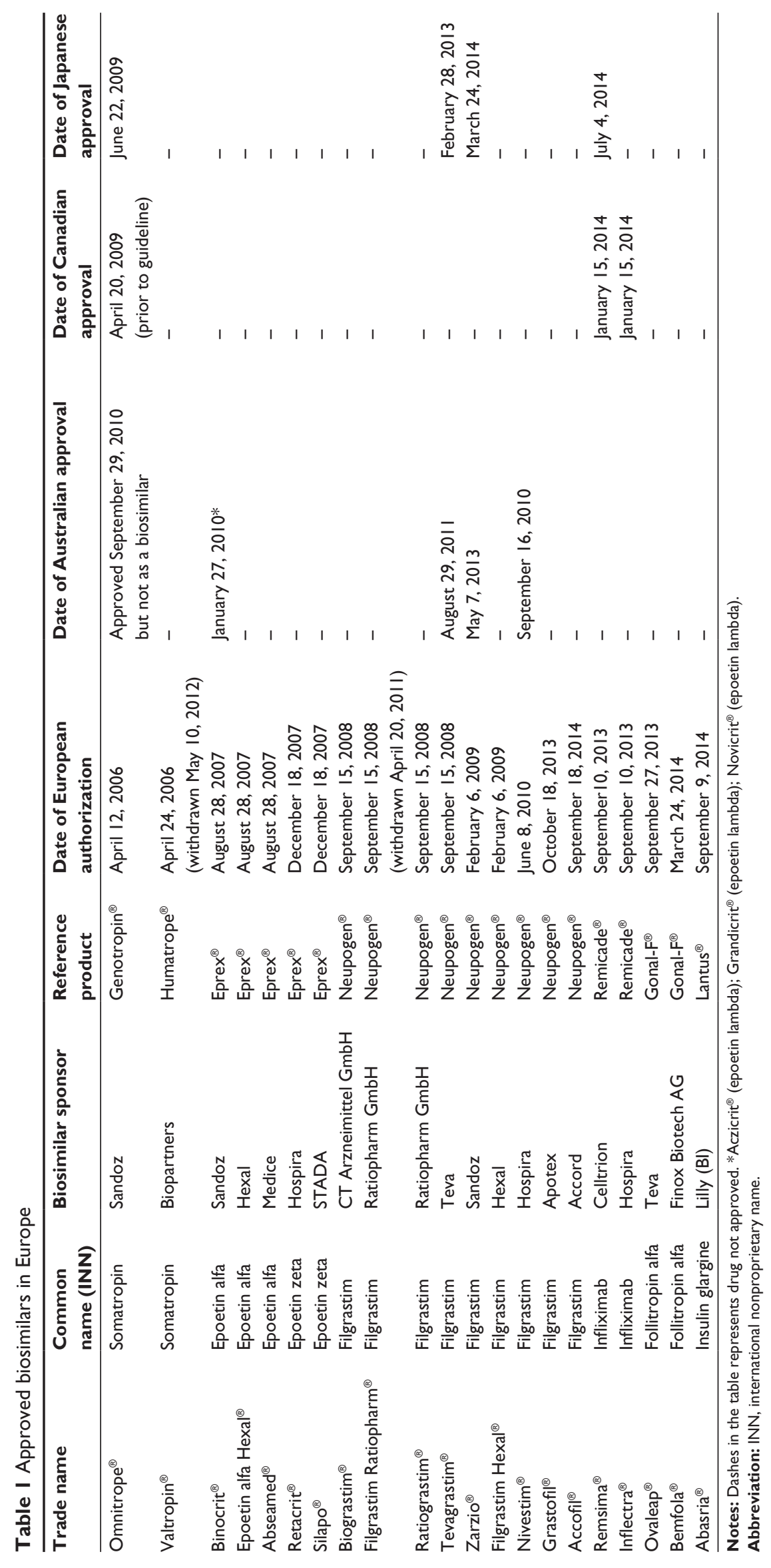


complexity and relative ease and predictability of chemical synthesis, approval of a generic drug simply requires sponsors demonstrate chemical identity and bioequivalence to a reference product. Limited confirmatory clinical trials are allowed to demonstrate bioequivalence, but pivotal clinical trials to demonstrate safety and effectiveness de novo are not needed (or in some markets like the US are not allowed). Conversely, a sponsor developing an originator biologic (through the stand-alone pathway) must demonstrate safety and effectiveness de novo with clinical trials in each indication. Neither of these development pathways is structured to demonstrate biosimilarity to a reference product. As a general rule, biologics are more structurally complex (and therefore more difficult to characterize) than generic drugs, often represent complex mixtures, and can be highly sensitive to changes in manufacturing. Determination of biosimilarity relies on the comparison to an already approved (and demonstratively safe and effective in all approved indications) reference product and is intended to be an abbreviated pathway to optimize cost savings and reduce time to market. As we describe later in this paper, a biosimilar sponsor can always decide to file a stand-alone biologics application and follow that pathway, resulting in different data collection.

There exists broad global agreement on the development framework for approval of biosimilars in the highly regulated markets following the principles contained in the EMA guidelines ${ }^{1}$ and, subsequently, the World Health Organization guidelines. ${ }^{2}$ As outlined in Figure 1, biosimilar development illustrates a paradigm shift from reliance on pivotal clinical trials demonstrating safety and efficacy in each desired indication, to utilizing analytical and functional head-tohead comparative testing between the potential biosimilar and the reference product to establish biosimilarity, with clinical trials (if any) taking on a reduced, confirmatory role in some (if any) indications. ${ }^{3}$ At least theoretically, in some markets, eg, the US, clinical trials may not be required at all for approval of a biosimilar. However, realistically, they will likely be required at least for the first biosimilars in the US. Biosimilars also have post-market commitments based on what has been learned through experience with the reference product and are subject to the same pharmacovigilance systems as originator products.

As a practical matter, to demonstrate biosimilarity, a biosimilar sponsor characterizes many lots (gathered over as large a window of time as possible) of the reference product and the biosimilar and compares the two in head-to-head structural and functional tests to identify differences. Given the sensitivity of the state-of-the art analytical and functional tests used (and the overlapping results they produce), intraproduct as well as inter-product variations can be expected, especially for more complex products. The biosimilar sponsor must explain all detected differences between their candidate and its reference. Any residual uncertainty about whether a difference is clinically meaningful or not will likely trigger confirmatory clinical trials beyond those studies required to demonstrate comparative pharmacokinetics

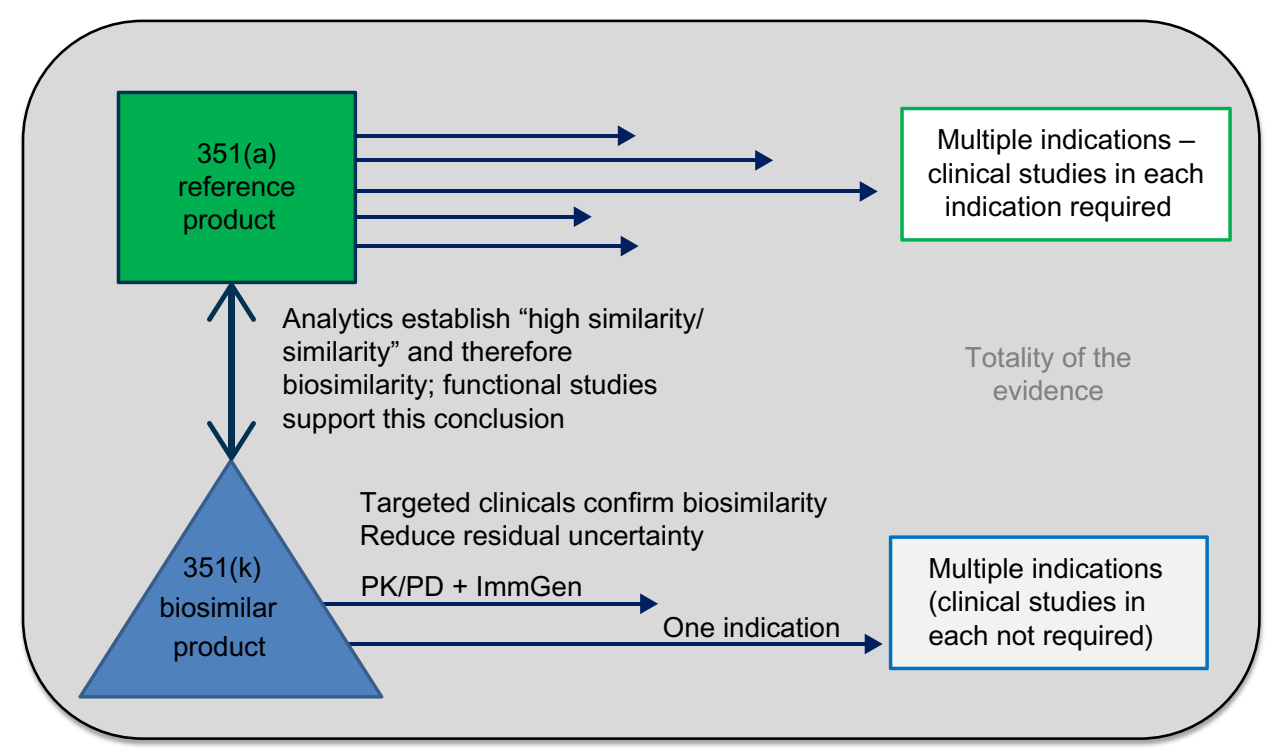

Figure I Stand-alone biologic vs biosimilar product development.

Notes: The analytical basis of biosimilarity: high similarity/similarity is the basis of biosimilarity and extrapolation. Clinical studies have a confirmatory role. 35 I (a), is the standalone biologic statutory approval pathway in the US. $35 \mathrm{I}(\mathrm{k})$, is the biosimilar and interchangeable biologic statutory approval pathway in the US.

Abbreviations: PK, pharmacokinetics; PD, pharmacodynamics; ImmGen, immunogenicity. 
$(\mathrm{PK}) /$ pharmacodynamics (PD) profiles and investigate potential immunogenicity. Of course, here we discuss likely regulatory data burdens. Another consideration is the benefit (versus cost) of conducting clinical trials to impact other stakeholders to prescribe, cover, or pay for the product. We note that even when (non-binding) guidance from regulatory agencies exists, sponsors can (unless prohibited by law) use their own elected means to meet applicable standards and data burdens, if scientifically/clinically justified and accepted by the regulatory agency.

Ultimately, all the data viewed together - the totality of the evidence - must demonstrate that the product is biosimilar to the reference product (eg, highly similar in the US, similar in other highly regulated markets). Anticipating how sponsors can meet this standard for a specific product remains challenging, not only because few biosimilars have been approved globally but because each regulatory decision is inherently product specific (ie, determined on a case-by-case basis with respect to the locally approved reference product). Some level of difference between a biosimilar and a reference product will undoubtedly be disqualifying, including the biosimilar candidate being a bio-better and displaying enhanced properties compared to the reference product. Ultimately, a biosimilar must be as good as and as bad as its reference in all clinically meaningful attributes.

In addition, but only in the US, a biosimilar product can be approved as an interchangeable biologic. The US law states that an interchangeable biologic can be substituted for the reference product at the pharmacy without the intervention of the prescribing physician. ${ }^{4,5}$ Without any examples of interchangeable biologics and little explanation yet from FDA on how to demonstrate that a biosimilar is an interchangeable biologic, it remains to be seen what the real value and burden for obtaining this designation will be. Clinical trials in which patients are switched from the reference product to the biosimilar (and back) are expected to be required.

Even though biosimilar sponsors may find it difficult to predict what a demonstration of biosimilarity looks like, it is important to acknowledge that regulatory agencies are experienced at making similar comparability determinations when they approve manufacturing process changes for biologic products. ${ }^{6}$ A comparability determination always includes complete extrapolation between indications and automatic interchangeability of pre- and post-change products. In fact, the EMA, Australia's Therapeutic Goods Administration (TGA), and Japan's Pharmaceuticals and Medical Devices Agency (PMDA) have stated that the similar standard of biosimilarity is the same similar standard governing approval of manufacturing changes. ${ }^{1,7,8}$ In addition, Health Canada stated that "Although the comparison of two independent products is outside of the scope of ICH Q5E, many of the principles and approaches are applicable". ${ }^{9}$ Because manufacturing process changes can result in differences between the pre- and post-manufacturing change products, including changes to post-translational modifications and immunogenicity, regulatory agencies require sponsors to compare the pre- and post-manufacturing change product to demonstrate comparability, but they almost never require a sponsor to conduct clinical trials. While this may not be required for all manufacturing changes, it is required in all highly regulated markets for all changes that potentially impact the safety and effectiveness of the product, at the regulatory agency's discretion. Unless a product fails comparability, the product appropriately continues on the market without interruption (with the same non-proprietary name and label). ${ }^{10}$ For some products, manufacturing process changes occur rather frequently. For example, a recent report shows that Remicade ${ }^{\circledR}$ has undergone 37 such changes in series since its approval in Europe. ${ }^{11}$ We note that the existence of manufacturing changes is public in Europe, but confidential in the US.

It is critical to the value of the biosimilar approval pathway that, in some circumstances, biosimilar sponsors can rely on extrapolation of data to gain approval for an indication in which they conducted no clinical studies. In fact, so far all the approved biosimilars in Europe were granted all the reference product's indications (at the time of the biosimilar's approval) without having to conduct clinical trials in every indication. However, sponsors cannot assume full extrapolation in all highly regulated markets, even if obtained in some regions. The biosimilar sponsor must justify the use of extrapolation for each indication to each of the regulatory agency's satisfaction.

This paper focuses on describing the unique role of clinical trials in the development of biosimilars, identifying key insights from case studies of biosimilars approved across highly regulated markets, and discussing future strategic considerations for biosimilar sponsors in a global marketplace.

\section{Learnings from biosimilar approvals to date}

We examine examples from four classes of products for which biosimilars are currently approved in multiple highly regulated markets - somatropins, filgrastims, epoetins, and infliximabs. We highlight key insights from the publicly available information regarding clinical studies included in 
regulatory dossiers submitted to gain approval in various highly regulated markets.

\section{Somatropins}

Somatropin is a very well-characterized, low-complexity, non-glycosylated 191-amino acid recombinant human growth hormone. Only one biosimilar somatropin product is currently marketed in Europe: Sandoz's Omnitrope ${ }^{\circledR}$, which was approved in Europe in 2006 and then in Canada and Japan in 2009 (reference product Genotropin $^{\circledR}$ ) (Table 2). A second somatropin, Valtropin ${ }^{\circledR}$, was approved as a biosimilar to Humatrope $^{\circledR}$ in Europe in 2006, but was withdrawn in 2012. Omnitrope ${ }^{\circledR}$ is approved in the US and Australia as well, but not through the biosimilar regulatory route. While regulatory agencies decide approval based on product, indication, and in some cases, class-specific characteristics, a single product with multiple global approvals such as Omnitrope ${ }^{\circledR}$ serves as a good case study to compare clinical trial data expectations across regions.

\section{PK/PD studies}

Biosimilar sponsors compare the biosimilar to the reference product on key PK parameters to demonstrate that they share similar PK profiles. For most if not all clinical trials, the sponsor also collects safety, efficacy, and/or PK/PD data outside of the primary objectives of a study. For example, an efficacy study can also add supportive data on PK/PD. Consistent with EMA guidelines, the sponsor, Sandoz, utilized a randomized, single-dose, two-way crossover design with $12-25$ healthy volunteers for all three PK studies. ${ }^{12-14}$
EMA prefers, when appropriate, for sponsors to use a singledose crossover study or for products with a long half-life or high risk of immunogenicity, a parallel group design. ${ }^{12,13,15}$ Healthy volunteers are routinely used as the most sensitive population to detect differences in PK between products, due to their lack of comorbidity and comedications. However, if healthy volunteers cannot be used, the study(s) is(are) ideally conducted in a patient population with the least variation among individuals. ${ }^{12,13,15}$

During product development, Sandoz made manufacturing changes (two additional purification steps), resulting in an earlier powder formulation and a proposed commercialization powder formulation. ${ }^{14}$ As such, Sandoz submitted three PK/PD studies comparing: 1) the earlier powder formulation to placebo; 2) the earlier powder formulation to Genotropin ${ }^{\circledR}$; and 3) the earlier powder formulation to a liquid formulation using the proposed commercialization powder to bridge the two formulations by demonstrating that they are comparable with respect to $\mathrm{PK} / \mathrm{PD}$ measures. ${ }^{14}$

\section{Confirmatory clinical studies}

As for PK/PD studies, EMA recommends that the study population for efficacy trials be sensitive and representative of the approved reference product indication(s) and for somatropins, this is treatment-naïve children with growth hormone deficiency (GHD). ${ }^{12,13,15}$ Sandoz conducted a confirmatory randomized efficacy study for Omnitrope ${ }^{\circledR}$ in almost 90 treatment-naïve children with human GHD, looking at various height measures to compare: 1) the effects of the earlier powder formulation to EU-sourced Genotropin ${ }^{\circledR}$ in an

Table 2 Clinical trials submitted for Omnitrope ${ }^{\circledR}$ (somatropin)

\begin{tabular}{|c|c|c|}
\hline Europe $^{14}$ & Canada ${ }^{16}$ & Japan $^{18}$ \\
\hline Three PK/PD two-way crossover trials of two formulations in & All EMA submitted studies plus: & All EMA, Health Canada, and the \\
\hline I2-25 healthy volunteers to bridge between pre- and post- & Two additional three-arm & US FDA submitted studies plus: \\
\hline manufacturing change biosimilar product during development: & crossover PK/PD studies in 32-35 & Additional three-arm crossover \\
\hline Pre- vs placebo & healthy volunteers comparing & PK trial in 54 healthy male \\
\hline Pre- vs reference product & Genotropin ${ }^{\circledR}$ with Omnitrope ${ }^{\circledR}$ & Japanese volunteers comparing \\
\hline Pre- vs post (commercialization) & powder, and either Omnitrope ${ }^{\circledR}$ & two concentrations of \\
\hline One confirmatory randomized efficacy study for Omnitrope ${ }^{\circledR}$ in almost & solution $(5 \mathrm{mg} / \mathrm{l} .5 \mathrm{~mL})$ or & Omnitrope ${ }^{\circledR}$ solution with \\
\hline 90 treatment-naïe children with human GHD looking at various heights & Omnitrope ${ }^{\circledR}$ solution & Genotropin ${ }^{\circledR}$ \\
\hline measures primary endpoints to compare I) the effects of the earlier & $(10 \mathrm{mg} / \mathrm{l} .5 \mathrm{~mL})$ (both powder and & \\
\hline powder formulation to Genotropin ${ }^{\circledR}$ (sourced from the EU) in an open-study & solutions to be commercialized) & \\
\hline over 9 months and 2) the effects of Omnitrope ${ }^{\circledR}$ and a liquid formulation & Additional single-arm confirmatory & \\
\hline using the proposed commercialization powder during the first 6 months of & long-term study of the Omnitrope ${ }^{\circledR}$ & \\
\hline the study (after which all patients were switched to the liquid formulation) & solution in $50 \mathrm{GHD}$ treatment-naïve & \\
\hline One open, multicenter, non-comparative, non-controlled & children with analyses conducted & \\
\hline confirmatory safety study of Omnitrope ${ }^{\circledR}$, evaluating I2-month & at 12 months, 24 months, and & \\
\hline data of $5 \mathrm{I}$ treatment-naïve children with GHD & 30 months & \\
\hline
\end{tabular}

Abbreviations: PK, pharmacokinetics; PD, pharmacodynamics; EMA, European Medicines Agency; FDA, Food and Drug Administration; EU, European Union; GHD, growth hormone deficiency. 
open-study over 9 months and 2) the effects of Omnitrope ${ }^{\circledR}$ and a liquid formulation using the proposed commercialization powder. ${ }^{14}$ Sandoz also conducted an open, multicenter, non-comparative, non-controlled confirmatory (ie, confirmatory of biosimilarity) safety study of Omnitrope ${ }^{\circledR}$, evaluating 12-month data of 51 treatment-naïve children with GHD. ${ }^{14}$ Immunogenicity assessments were conducted throughout all clinical trials. ${ }^{14}$

In Europe, Omnitrope ${ }^{\circledR}$ received approval for all the indications (full extrapolation) of the reference product Genotropin $^{\circledR}$ (somatropin), including treating children with growth disturbances due to various factors and as replacement therapy in adults with pronounced GHD. Post-market commitments apply to biosimilars in Europe just as for originator products. In this paper we do not discuss any post-approval trial commitments.

\section{Additional studies for subsequent market approvals}

Canada. Sandoz included all clinical trials from the EMA submission in the data package submitted to Health Canada. ${ }^{16}$ In addition, Sandoz submitted two new PK/PD studies: two 3-arm crossover studies in 32-35 healthy volunteers comparing Genotropin ${ }^{\circledR}$ with Omnitrope ${ }^{\circledR}$ powder and either Omnitrope ${ }^{\circledR}$ solution $(5 \mathrm{mg} / 1.5 \mathrm{~mL})$ or Omnitrope ${ }^{\circledR}$ solution $(10 \mathrm{mg} / 1.5 \mathrm{~mL})$ (both powder and solutions to be commercialized). ${ }^{16}$ Apparently, Health Canada required these additional studies to demonstrate bioequivalence among the different formulations and strengths of the Omnitrope ${ }^{\circledR}$ products seeking approval. Interestingly, in contrast to the EMA guidelines, Canadian guidelines recommend that sponsors conduct PK studies in the relevant patient population because "results from healthy subjects may not adequately reflect the PK parameters in the patient population where the product is indicated". ${ }^{9}$ However, Health Canada recognizes that when justifiable and where there is no undue risk, PK studies may be conducted in healthy volunteers. $^{9}$

In addition, Health Canada apparently required one additional clinical study in treatment-naïve children with GHD as well as additional confirmatory analyses of original studies. ${ }^{16}$ Sandoz conducted a single-arm confirmatory longterm safety and efficacy study of the Omnitrope ${ }^{\circledR}$ solution in 50 GHD treatment-naïve children with analyses conducted at 12 months, 24 months, and 30 months. ${ }^{16}$ As described in Health Canada's guidance:

[...] comparative clinical trials are critically important to demonstrate the similarity in efficacy and safety profiles between the SEB and the reference biologic drug with few exceptions (eg, recombinant human soluble insulin products for which only a comparative clinical safety study is required). ${ }^{9}$

Omnitrope ${ }^{\circledR}$ received approval for all the indications of the reference product Genotropin ${ }^{\circledR}$. Health Canada explained that extrapolation from the pediatric population to adults:

[...] was justified on the basis that Omnitrope ${ }^{\circledR}$ and

Genotropin ${ }^{\circledR}$ had similar quality characteristics, comparable

non-clinical and clinical profiles supported by data, and a

written clinical/scientific rationale by the sponsor. ${ }^{16}$

Japan. Sandoz included all clinical trials conducted to date, including those submitted to EMA, Health Canada, and the US FDA (non-biosimilar 505(b)(2) New Drug Application ${ }^{17}$ ) submission in the data package submitted to the Japanese PMDA. In addition, the Japanese PMDA apparently required an additional PK study consisting of a three-period crossover trial in 54 healthy male Japanese volunteers comparing two concentrations of Sandoz's product with Genotropin ${ }^{\circledR} .{ }^{18}$

Omnitrope ${ }^{\circledR}$ was approved for all indications of the reference product Genotropin ${ }^{\circledR}$ in Japan. Similar to other highly regulated markets, sponsors can obtain extrapolation in Japan if sufficiently justified; however:

[...] where each relevant indication have [sic] a different mechanism of action or the mechanism of each indication remains unclear, the comparability of efficacy with the original biologic should be demonstrated for each indication, without extrapolation. ${ }^{7}$

According to Japanese regulators, for Omnitrope ${ }^{\circledR}$ :

[...] it was possible to extrapolate from one indication GHD in pediatric population to the other indications, such as Turner Syndrome and chronic renal insufficiency in Japan since the mechanism of action was the same. ${ }^{18}$

\section{Filgrastims}

Recombinant filgrastim is a well-characterized, lowcomplexity, 175 amino acid non-glycosylated methionyl human granulocyte colony stimulating factor (G-CSF). Filgrastim stimulates the growth of neutrophils to prevent serious infections in patient undergoing chemotherapy. Four separate European dossiers ${ }^{19-22}$ support the nine filgrastim biosimilars approved in Europe (one of these nine has been withdrawn). Each of the filgrastims was granted all the reference product, Neupogen ${ }^{\mathbb{R}}$ 's indications (in part because the mechanism of action [MOA] is the same in all indications). Of the eight biosimilar filgrastims in Europe, three 
Table 3 Filgrastim biosimilar clinical trials in Europe

\begin{tabular}{|c|c|}
\hline Product & Europe \\
\hline Biograstim ${ }^{\circledR}$, & Two PK/PD crossover studies comparing filgrastim to Neupogen ${ }^{\circledR}$ in 56 or I44 healthy volunteers (IV and SC) \\
\hline \multirow[t]{3}{*}{ (filgrastim) } & $\begin{array}{l}\text { One randomized, placebo, and active control efficacy study comparing filgrastim to Neupogen }{ }^{\circledR} \text { in } 348 \text { breast cancer patients } \\
\text { receiving chemotherapy }\end{array}$ \\
\hline & Two randomized, active control safety studies comparing filgrastim to Neupogen ${ }^{\circledR}$ in 240 lung cancer patients receiving \\
\hline & chemotherapy or 92 non-Hodgkin’s lymphoma patients receiving chemotherapy \\
\hline $\begin{array}{l}\text { Ratiograstim }{ }^{\circledR} \\
\text { (filgrastim) }\end{array}$ & Same as Biograstim ${ }^{\circledR}$ \\
\hline $\begin{array}{l}\text { Tevagrastim }{ }^{\circledR}, \\
\text { (filgrastim) }\end{array}$ & Same as Biograstim ${ }^{\circledR}$ \\
\hline Zarzio ${ }^{\circledR}$ & Four PK/PD randomized, double-blind, two-way crossover studies in 24-40 healthy volunteers studying two routes (IV and SC) \\
\hline (filgrastim) n & and four doses. One open, single-arm, multicenter safety study in 170 breast cancer patients receiving chemotherapy \\
\hline $\begin{array}{l}\text { Filgrastim Hexal }{ }^{\circledR} \text {, } \\
\text { (filgrastim) }\end{array}$ & Same as Zarzio ${ }^{\circledR}$ \\
\hline $\begin{array}{l}\text { Nivestim }{ }^{\circledR} \\
\text { (filgrastim) }\end{array}$ & $\begin{array}{l}\text { Two PK/PD randomized, two-way crossover studies in } 44 \text { or } 48 \text { healthy volunteers. One randomized, double-blind safety and } \\
\text { efficacy study in } 279 \text { breast cancer patients receiving chemotherapy }\end{array}$ \\
\hline Grastofil $^{\circledR}$ & Four PK/PD randomized, double-blind studies in healthy volunteers: I) a two-way crossover study (IV) in 36 subjects; \\
\hline \multirow[t]{4}{*}{ (filgrastim) } & 2) a two-way crossover study (SC) in 73 subjects; 3) a repeat-dose, parallel group, active- and placebo-controlled study \\
\hline & in 78 subjects; and 4) a single-dose, randomized double-blind active-controlled comparative three-way crossover study in \\
\hline & 48 healthy volunteers comparing Grastofil ${ }^{\circledR}$, EU-approved Neupogen ${ }^{\circledR}$, and US-licensed Neupogen ${ }^{\circledR}$ \\
\hline & $\begin{array}{l}\text { One single-arm, open-label safety study in } 120 \text { breast cancer patients undergoing chemotherapy (not comparative; used historical } \\
\text { data about Neupogen }{ }^{\circledR} \text { ) }\end{array}$ \\
\hline $\begin{array}{l}\text { Accofil }^{\circledR}, \\
\text { (filgrastim) }\end{array}$ & Same as Grastofil ${ }^{\circledR}$ \\
\hline
\end{tabular}

Abbreviations: PK, pharmacokinetics; PD, pharmacodynamics; IV, intravenous; SC, subcutaneous; EU, European Union.

have been approved in Australia and two in Japan (Table 3). The biosimilar filgrastims are a good case study for looking at clinical trial submissions across different sponsors for the same molecule within the same market, Europe.

\section{PK/PD studies}

Product-specific EMA guidelines recommend using a singledose crossover study(s) in healthy subjects using subcutaneous (SC) and intravenous (IV) administration of the products to compare $\mathrm{PK} / \mathrm{PD}$ parameters between the biosimilar and the reference product. ${ }^{23} \mathrm{CT}$ Arzneimittel/Ratiopharm/Teva (Biograstim $^{\circledR} /$ Ratiograstim $^{\circledR} /$ Tevagrastim $^{\circledR}$ ) submitted two PK/PD crossover studies comparing filgrastim to Neupogen ${ }^{\circledR}$ in 56 and 144 healthy volunteers (IV and SC). ${ }^{19,24,25}$ Similarly, Hospira $\left(\right.$ Nivestim $^{\circledR}$ ) submitted two PK/PD randomized, twoway crossover studies in 44 and 48 healthy volunteers. ${ }^{21}$

Sandoz/Hexal $\left(\right.$ Zarzio $^{\circledR} /$ Filgrastim Hexal $^{\circledR}$ ) submitted four PK/PD randomized, double-blind, two-way crossover studies in $24-40$ healthy volunteers studying two routes (IV and SC) and four doses..$^{20,26}$ Apotex/Accord (Grastofil ${ }^{\circledR /}$ Accofil ${ }^{\circledR}$ ) submitted four PK/PD randomized, double-blind studies in healthy volunteers: 1) a two-way crossover study (IV) in 36 subjects; 2) a two-way crossover study (SC) in 73 subjects; 3 ) a repeat-dose, parallel group, active- and placebocontrolled study in 78 subjects; and 4) a single-dose, randomized, double-blind, active-controlled, comparative three-way crossover study in 48 healthy volunteers comparing Grastofil ${ }^{\circledR}$, EU-approved Neupogen ${ }^{\circledR}$, and US-licensed Neupogen ${ }^{\circledR}$ to confirm no meaningful differences between pre- and postmanufacturing change products (ie, a bridging study)..$^{22,27}$

\section{Confirmatory clinical studies}

According to EMA guidelines for clinical efficacy studies for G-CSF biosimilars:

$[\ldots]$ the recommended clinical model for the demonstration of comparability of the test and the reference medicinal product is the prophylaxis of severe neutropenia after cytotoxic chemotherapy in a homogenous patient group (eg, tumour type, previous and planned chemotherapy as well as disease stage)..$^{23}$

Accordingly, CT Arzneimittel/Ratiopharm/Teva (Biograstim $^{\circledR} /$ Ratiograstim $^{\circledR} /$ Tevagrastim $^{\circledR}$ ) submitted one randomized, placebo, and active control efficacy study comparing filgrastim to Neupogen ${ }^{\circledR}$ in 348 breast cancer patients receiving chemotherapy and two randomized, active control safety studies comparing filgrastim to Neupogen ${ }^{\circledR}$ in 240 lung cancer patients receiving chemotherapy or 92 non-Hodgkin's lymphoma patients receiving chemotherapy. ${ }^{19,24,25}$ Similarly, Hospira $\left(\right.$ Nivestim $\left.^{\circledR}\right)$ submitted one randomized, doubleblind safety and efficacy study in 279 breast cancer patients receiving chemotherapy. ${ }^{21}$ 
However, EMA guidelines allow for PK/PD studies to confirm comparability of efficacy in the absence of an efficacy trial if there exists a validated surrogate PD marker/ biomarker that can be related to patient outcome "to the extent that demonstration of similar effect on the PD marker will ensure a similar effect on the clinical outcome". ${ }^{15,23}$ Furthermore, EMA has identified a number of such cases in which PK/PD studies may be sufficient to confirm biosimilarity, including the use of absolute neutrophil count as a biomarker for filgrastim biosimilars. ${ }^{15}$

Apparently, Sandoz/Hexal (Zarzio ${ }^{\circledR} /$ Filgrastim Hexal $^{\circledR}$ ) and Apotex/Accord (Grastofil ${ }^{\circledast} /$ Accofil $^{\circledR}$ ) aimed to do just that. Sandoz/Hexal submitted one open, single-arm, multicenter safety study in 170 breast cancer patients receiving chemotherapy. ${ }^{20,26}$ EMA explained that:

[...] in line with CHMP Scientific Advice, PD data in healthy volunteers (absolute neutrophil and CD34+ cell counts) were presented to establish the clinical efficacy. ${ }^{20,26}$

Similarly, Apotex/Accord submitted one single-arm, open-label safety study in 120 breast cancer patients undergoing chemotherapy (not comparative; used historical data about Neupogen $\left.{ }^{\circledR}\right) .22,27$ According to EMA:

[...] although the clinical efficacy and safety data submitted were from a single uncontrolled clinical study, it should be noted that in a G-CSF biosimilar MAA, robust PD data in healthy volunteers could be considered pivotal, as in this case. ${ }^{22,27}$

Clearly, sponsors electing to minimize the clinical studies they conduct is integral to the very concept of biosimilarity and an abbreviated regulatory pathway.

\section{Additional studies for subsequent other market approvals}

Tevagrastim ${ }^{\circledR}$, Zarzio $^{\circledR}$, and Nivestim ${ }^{\circledR}$ have been approved in Australia (and Tevagrastim ${ }^{\circledR}$ and Zarzio ${ }^{\circledR}$ additionally in Japan). The sponsors of these products appear to have submitted the same data packages to Australia's TGA as submitted to EMA. ${ }^{28-30}$ The TGA's approach matches that of EMA given that TGA has adopted several EMA biosimilar guidelines as their own standards, including the G-CSF biosimilar guideline. ${ }^{8}$ As such, TGA allows for PK/PD studies to confirm comparability of efficacy, as does Japan. ${ }^{7}$

Sandoz's biosimilar application for Zarzio ${ }^{\circledR}$ (named Zarxio $^{\circledR}$ ) was filed in the US as the first 351(k) biosimilar biologics license application, and was approved for all indications of the reference product Neupogen on March 6, 2015.

\section{Epoetins}

Recombinant erythropoietin (epoetin) is a well-characterized, single chain, 165 amino acid glycoprotein that stimulates red blood cell production. There are five epoetin biosimilars approved in Europe, which differ in glycosylation pattern, supported by two regulatory dossiers (Table 4) ${ }^{31,32}$ The reference product Eprex $^{\circledR} / \mathrm{Erypo}^{\circledR}$ (epoetin alfa) is approved to treat anemia in patients with chronic renal failure, anemia in cancer patients due to chemotherapy, and for increasing production of autologous blood in patients prior to blood donation.

\section{PK/PD studies}

EMA's product-specific guideline for epoetins recommends biosimilar sponsors compare their product with the reference product in a single-dose crossover study in healthy volunteers

Table 4 Epoetin biosimilar clinical trials

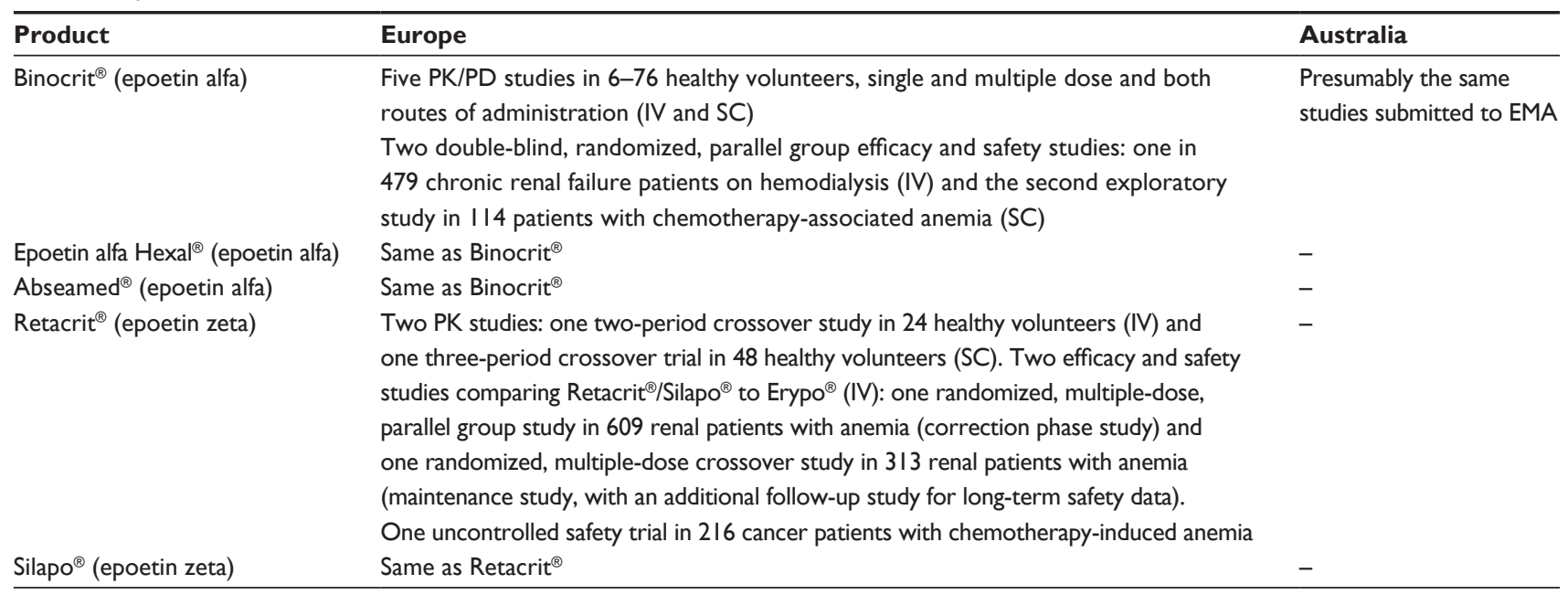

Note: Dashes in the table represents drug not approved.

Abbreviations: PK, pharmacokinetics; PD, pharmacodynamics; IV, intravenous; SC, subcutaneous; EMA, European Medicines Agency. 
for the desired routes of administration (SC and/or IV). ${ }^{33}$ For Binocrit $^{\circledR} /$ Epoetin alfa Hexal ${ }^{\circledR} /$ Abseamed $^{\circledR}$, Sandoz/Hexal/ Medice submitted five PK/PD studies: one pilot open, randomized, four-way, crossover study in six healthy volunteers comparing Binocrit ${ }^{\circledR}$ to Eprex $^{\circledR}$ (IV/SC); one pivotal open, randomized, parallel group repeat-dose study in 76 healthy volunteers comparing Binocrit ${ }^{\circledR}$ to $\operatorname{Eprex}^{\circledR}$ (IV); one study in 72 healthy volunteers comparing Binocrit ${ }^{\circledR}$ to NeoRecormon ${ }^{\circledR}$ (SC) (not relevant to the demonstration of biosimilarity); one study in six healthy individuals looking at Binocrit ${ }^{\circledR}$ (SC; no comparator, supportive data for PK); and one pivotal open, randomized, parallel group study requested by EMA in 74 healthy volunteers comparing Binocrit ${ }^{\circledR}$ to $\operatorname{Eprex}^{\circledR}$ (SC). ${ }^{31,34,35}$

Similarly, Hospira/STADA $\left(\right.$ Retacrit $^{\circledR} /$ Silapo $^{\circledR}$ ) submitted a two-period crossover PK study in 24 healthy volunteers comparing their product to Erypo ${ }^{\circledR}$ after a single IV dose. ${ }^{32,36}$ They also submitted a three-period crossover comparative PK study in 48 healthy volunteers after a single SC dose. ${ }^{32,36}$ Interestingly, no specific PD studies were submitted. As EMA explained:

The Guideline on similar medicinal products containing recombinant erythropoietins suggests that a PD study be performed investigating reticulocyte count as the most relevant pharmacodynamic marker for assessment of the activity of epoetin. ${ }^{36}$

However, because the guidance was not available when Hospira/STADA conducted their studies and biosimilar application requirements were still in flux, EMA stated that:

Although PD studies should be part of the development programme for a biosimilar epoetin, the lack of such studies is not critical since demonstration of similar efficacy and safety between the new and the reference product is required anyway. ${ }^{36}$

\section{Confirmatory clinical studies}

EMA's product-specific guideline for epoetins recommends that biosimilar sponsors conduct at least two randomized, parallel group efficacy and safety trials in patients with renal anemia for both routes of administration. ${ }^{33}$ The guideline explains that:

[...] this could be achieved by performing separate clinical trials for both routes or by performing one clinical trial for one route and providing adequate bridging data for the other route. ${ }^{33}$

Because the MOA of epoetin is the same in all approved indications, a demonstration of efficacy and safety in renal anemia will allow extrapolation to other indications with the same route of administration. ${ }^{33}$
Sandoz/Hexal/Medice (Binocrit ${ }^{\circledR} /$ Epoetin alfa $\mathrm{Hexal}^{\circledR} /$ Abseamed $^{\circledR}$ ) requested all indications of the reference product, except increasing production of autologous blood in patients prior to blood donation (apparently based on the fact that unexpired patent rights covered this indication at the time). ${ }^{37-39}$ They submitted two double-blind, randomized, parallel group efficacy and safety studies. ${ }^{31,34,35}$ One in 479 chronic renal failure patients on hemodialysis (IV) started as an equivalence study and after a four-week evaluation period, transformed into an open-label safety study with all study participants switched to Binocrit ${ }^{\circledR} /$ Epoetin alfa Hexal $^{\circledR} /$ Abseamed $^{\circledR}$.

The second was an exploratory study in 114 patients with chemotherapy-associated anemia (SC). ${ }^{31,34,35}$ This second study was not a (guideline recommended) comparative study for SC administration in renal patients because at the time Eprex ${ }^{\circledR} /$ Erypo $^{\circledR}$ was contraindicated for SC use in renal patients. Thus, Sandoz/Hexal/Medice could not use it as a comparator and conduct the recommended trial (which EMA accepted given the circumstances). They instead conducted the study in cancer patients even though the study was not designed to demonstrate comparability between Binocrit ${ }^{\circledR} /$ Epoetin alfa Hexal ${ }^{\circledR} /$ Abseamed $^{\circledR}$ and Eprex ${ }^{\circledR} /$ Erypo $^{\circledR}$, but was considered very useful by EMA because dosages to treat cancer patients are routinely much higher than those used in renal patients. ${ }^{31,34,35}$ EMA concluded that even though the study could not establish comparable efficacy for SC use, because Sandoz/Hexal/Medice demonstrated:

\section{[...] equivalent efficacy and steady state pharmacokinetics and pharmacodynamics for IV administered [Binocrit ${ }^{\mathbb{B}}$ / Epoetin alfa Hexal ${ }^{\circledR} /$ Abseamed $\left.^{\circledR}\right]$ and Eprex $^{\circledR} /$ Erypo $^{\circledR}$, and the finding of similar multiple-dose SC pharmacokinetic/ pharmacodynamic profiles in healthy volunteers, a differ- ence in efficacy for the SC route of administration appears highly unlikely. ${ }^{31,34,35}$}

Binocrit $^{\circledR} /$ Epoetin alfa Hexal ${ }^{\circledR} /$ Abseamed $^{\circledR}$ was approved for all indications requested. However, EMA did not recommend the SC use of Binocrit ${ }^{\circledR} /$ Epoetin alfa $\mathrm{Hexal}^{\circledR} /$ Abseamed $^{\circledR}$ in renal patients. ${ }^{31,34,35}$

In 2008, presumably after the blocking patent expired, EMA approved Binocrit ${ }^{\circledR} /$ Epoetin alfa Hexal ${ }^{\circledR} /$ Abseamed $^{\circledR}$ for the final indication: "increasing the yield of autologous blood from patients in pre-donation program". ${ }^{37-39}$ EMA allowed extrapolation from the data submitted in the original application to that indication (without requiring any additional clinical data) based on: 1) the biosimilar PK/PD data in both routes of administration; 2) equivalent efficacy and safety data in renal anemia; and 3 ) the fact that epoetin has same MOA in all indications. ${ }^{37-39}$ 
Similarly, Hospira/STADA submitted two efficacy and safety studies comparing Retacrit ${ }^{\circledR} /$ Silapo $^{\circledR}$ to Erypo $^{\circledR}$ (IV): one randomized, multiple-dose, parallel group study in 609 renal patients with anemia (correction phase study) and one randomized, multiple-dose crossover study in 313 renal patients with anemia (maintenance study, with an additional follow-up study for long-term safety data). ${ }^{32,36}$ In addition, Hospira/STADA submitted one uncontrolled safety trial with 216 cancer patients with chemotherapy-induced anemia. ${ }^{32,36} \mathrm{As}$ was the case for Sandoz/Hexal/Medice (Binocrit ${ }^{\mathbb{R}} /$ Epoetin alfa Hexal $^{\circledR} /$ Abseamed $^{\circledR}$ ), Hospira/STADA were prevented from conducting an SC comparative trial in renal anemia patients because of Erypo ${ }^{\circledR}$ 's contraindication at that time. ${ }^{32,36}$

The data from the Retacrit/Silapo studies demonstrated comparable efficacy for use by IV, and EMA explained that it concluded that similar efficacy can be assumed for the SC use because of the similar efficacy for the IV route and:

[...] the similarity of PK profiles, especially bioavailability, for both the IV and SC route of administration suggests similar efficacy also for SC use. The comparison of the efficacy data from the oncology trial with published data are in line with this conclusion. ${ }^{32,36}$

Retacrit ${ }^{\circledR} /$ Silapo $^{\circledR}$ was approved for all indications requested (all except increasing production of autologous blood in patients prior to blood donation). However, EMA did not recommend the SC use of Retacrit ${ }^{\circledR} /$ Silapo $^{\circledR}$ in renal patients. Hospira/STADA withdrew their request for exclusive $\mathrm{SC}$ indications in immunocompetent patients (eg, "reduction of allogeneic blood transfusions in adult non-iron deficient patients prior to major elective orthopaedic surgery"). ${ }^{32,36}$

In September 2009, Hospira/STADA (Retacrit ${ }^{\circledR} /$ Silapo $^{\circledR}$ ) submitted data from a maintenance treatment of 679 renal patients (SC), which lead to the product's approval for the $\mathrm{SC}$ route of administration in renal patients with anemia in April 2010. ${ }^{40,41}$

In June 2011, EMA extrapolated data to grant Hospira $\left(\right.$ Retacrit $\left.^{\circledR}\right)$ the indication:

[...] to reduce exposure to allogeneic blood transfusions in adult non-iron deficient patients prior to major elective orthopaedic surgery, having a high perceived risk for transfusion complications. ${ }^{42}$

\section{Additional studies for subsequent other market approvals}

Novartis Pharmaceuticals Australia received approval for its biosimilar Novicrit ${ }^{\circledR}$ (epoetin lambda), marketed as Binocrit ${ }^{\circledR}$ (epoetin alfa) in Europe, in January 2010 in Australia. ${ }^{43}$ The product received the following indications: treatment of renal anemia, treatment of chemotherapy-induced anemia, treatment of elective surgery patients with anemia, and to augment autologous blood collection prior to major elective surgery. ${ }^{43}$ TGA had concluded that even though epoetin lambda and epoetin alfa shared the same amino acid sequence:

$[\ldots]$ there were significant differences in the glycosylation pattern of this product and epoetin alfa which made it appropriate for the former to have the different Australian Biologic Name, epoetin lambda. ${ }^{43}$

\section{Infliximabs}

Infliximab is a chimeric human-murine IgG1 monoclonal antibody (mAb). Because of their large size and posttranslational modifications (eg, glycosylation), mAbs fall on the high end of the structural complexity scale. Infliximab binds to tumor necrosis factor alpha (TNF- $\alpha$ ) to inhibit TNF- $\alpha$-mediated cell signaling that leads to cell proliferation. Infliximab also activates immune responses (eg, antibodydependent cell-mediated cytotoxicity [ADCC]). The approval of biosimilar infliximabs, as the most complex molecules yet approved as biosimilars, illustrates the additional complexity in clinical data burdens and current uncertainty in extrapolation for complex biosimilars.

The reference product, Remicade $^{\circledR}$ (infliximab), is approved in Europe for eight indications: Crohn's disease (CD), pediatric $\mathrm{CD}$, ulcerative colitis $(\mathrm{UC})$, pediatric $\mathrm{UC}$, rheumatoid arthritis (RA), psoriatic arthritis (Ps), ankylosing spondylitis (AS), and plaque psoriasis. Celltrion developed a biosimilar infliximab and splits global marketing rights to the product with Hospira, each commercializing the product in different regions. This product was first approved in South Korea as a biosimilar in July $2012 .{ }^{44}$ This one product - approved as separate biosimilars sharing a data package - is marketed in Europe (by Celltrion as Remsima ${ }^{\circledR}$ or by Hospira as Inflectra ${ }^{\circledR}$ ), Canada (by Celltrion as Remsima ${ }^{\circledR}$ or by Hospira as Inflectra ${ }^{\circledR}$ ), and Japan (by Celltrion as Remsima ${ }^{\circledR}$ ). In addition, Celltrion filed a biosimilar application in the US in 2014, and if approved, will be marketed by Hospira.

\section{PK/PD studies}

Celltrion's/Hospira's European data package included one preliminary randomized, double-blind, parallel group study "to evaluate the initial pharmacokinetics, efficacy, and safety of [Celltrion's/Hospira's infliximab] compared with Remicade when co-administered with methotrexate" in 19 patients with 
active RA for over 100 weeks. ${ }^{45,46}$ In addition, they submitted one parallel group PK study comparing their infliximab to Remicade $^{\circledR}$ in 250 AS patients. ${ }^{45,46}$ According to the Remsima ${ }^{\circledR}$ and Inflectra ${ }^{\circledR}$ EPARs:

Due to the long half-life and immunogenicity of infliximab, a parallel group design was considered appropriate and allowed the comparison of the PK and immunogenicity of CT-13 [biosimilar infliximab] and Remicade in a sensitive patient population..$^{45,46}$

The size of this trial, more than two to ten times larger than those conducted for the somatropin or filgrastim biosimilars described earlier, follows the suggestion of the EMA guideline for biosimilar MAbs that notes that MAbs have large personto-person variation in PK parameters and therefore cannot be compared with their reference products in a small PK study. ${ }^{47}$

In addition, the use of AS patients instead of healthy volunteers is consistent with EMA guidelines for biosimilar MAbs, which recommend conducting PK studies in a "sufficiently sensitive and homogeneous population". ${ }^{47}$ As explained by EMA:

$[\ldots]$ patients with AS were considered as a sensitive population, because these patients are generally young, otherwise healthy and not receiving concomitant medication such as MTX, which has been shown to have an effect on antiinfliximab antibody status and thus on infliximab clearance (Xu et al, 2008). ${ }^{45,46}$

\section{Confirmatory clinical studies}

Celltrion/Hospira submitted one efficacy/safety study for approval in Europe - a randomized, double-blind, parallel efficacy, and safety study comparing their infliximab to Remicade ${ }^{\circledR}$ when co-administered with methotrexate in 606 RA patients. ${ }^{45,46}$ As EMA explained:

[...] a single pivotal equivalence trial comparing the test and reference products is considered adequate to support this biosimilar application. ${ }^{45,46}$

EMA also mentioned that:

The choice of the indication (RA), the clinical setting (patients not adequately controlled with MTX), the primary endpoint (ACR20 at Week 30) and the equivalence margin $( \pm 15 \%)$ are in line with the CHMP guidance and were endorsed in CHMP scientific advice. ${ }^{45,46}$

In addition, immunogenicity was monitored in all three studies given that infliximab, as a chimeric mAb, is known to be highly immunogenic..$^{45,46}$

\section{Extrapolation}

Extrapolation represents the primary value of the biosimilars development pathway as it allows reduced clinical trial data burden (saving both time and lowering costs of development). It allows biosimilar sponsors to rely on a demonstration of analytical similarity with the reference product and other confirmatory evidence to support approval in an indication for which no clinical trials are conducted by the biosimilar sponsor. All regulatory agencies in highly regulated markets require a biosimilar sponsor to scientifically justify any request for extrapolation of data.

EMA concluded that extrapolation to all indications of the reference product was warranted for Remsima ${ }^{\circledR} /$ Inflectra $^{\circledR}$. As EMA explained:

[...] based on the results of the extensive in vitro and ex vivo comparability data on all functionalities of the infliximab molecule, including several experiments especially relevant to IBD. ${ }^{45,46}$

EMA also noted that additional support for extrapolation came from:

[...] increasing genetic and immunological evidence of a clinical and histological overlap between gut inflammation in spondyloarthropathies and $\mathrm{CD}$, [and] preliminary clinical data from [...] patients with $\mathrm{CD}$ and $\mathrm{UC}$ indicate similar response to CT-P13 compared with historical data on Remicade. ${ }^{45,46}$

Of note, structural testing showed that the biosimilar had less afucosylated antibodies in its product mixture, which results in lower FcRIIIa binding and less in vitro ADCC, one of the hypothesized mechanisms of action for anti-TNF products in inflammatory bowel disease (IBD). ${ }^{45,46}$ However, EMA did not consider this difference clinically meaningful because "it did not affect the activities of Remsima ${ }^{\circledR}$ in experimental models regarded as more relevant to the pathophysiological conditions in patients". ${ }^{45,46}$

\section{Other highly regulated market approvals}

With apparently the same data submitted to EMA, Health Canada came to a different conclusion and only granted extrapolation for some indications. ${ }^{48,49}$ Remsima $^{\circledR}$ and Inflectra ${ }^{\circledR}$ are approved in Canada for RA, Ps, AS, and plaque psoriasis, but not (yet) approved for $\mathrm{CD}$, pediatric $\mathrm{CD}, \mathrm{UC}$, and pediatric UC. ${ }^{48,49}$

As in other regions, Health Canada does allow extrapolation in certain circumstances. In the summary basis for 
decision, the agency explained that similarity with the reference product, the absence of meaningful differences, and scientific rationales submitted by the sponsor allowed for approval of psoriatic arthritis and plaque psoriasis, but:

[...] extrapolation to indications and uses pertaining to Crohn's disease and ulcerative colitis could not be recommended due to differences between Remsima and the reference product, that could have an impact on the clinical safety and efficacy of these products in these indications ${ }^{48,49}$

The agency was concerned by differences in the level of afucosylation, Fc $\gamma$ RIIIa receptor binding, and some in vitro ADCC assays. ${ }^{48,49}$ Whereas EMA, faced with the same data, decided that these differences did not preclude extrapolation, Health Canada felt that clinical differences between the biosimilar and reference product for these indications (ie, IBDs), given that ADCC may represent an important MOA in IBDs (but not other indications), could not be ruled out.

Remsima $^{\circledR}$ was approved in Japan on July 4, 2014 to treat certain patients suffering from rheumatoid arthritis, Crohn's disease, and moderate to severe ulcerative colitis. ${ }^{50}$

Celltrion announced that it had submitted a biosimilar application in the US for its infliximab biosimilar on August 9, 2014, and a decision is expected by mid-2015.

\section{Future strategy considerations for biosimilar development globally Global biosimilar regulatory strategy}

Given broad consensus among regulatory agencies in highly regulated markets regarding a biosimilar development framework (and the fact that most guidelines/guidances are not binding on the sponsor, ie, the sponsor can deviate from the recommendations if justified), it would appear to be easy to satisfy all parties with a single, biosimilar development plan. However, this is not always the case.

One reason is that regulatory agencies, including Europe, the US, Canada, and Australia, require that the biosimilar be compared to a reference product approved in that region..$^{1,3,7-9}$ Biosimilar sponsors can in some cases use comparative analytical and functional studies to bridge between reference products approved in different regions (the reference often being sourced from a single drug substance manufacturing site for worldwide distribution). Many biosimilar sponsors have relied on the same basic data package with additional such bridging studies as necessary. Regulators have developed evidentiary standards to qualify a product as equivalent to the reference product approved in their region. EMA and FDA both recommend that a biosimilar sponsor conduct three-way studies (analytical and possibly $\mathrm{PK} / \mathrm{PD}$ ) comparing the proposed biosimilar, the reference product used in the studies, and the regionally approved reference product. ${ }^{1,3}$ Health Canada allows a biosimilar applicant to use a reference product from a market that has an established relationship with Health Canada, has formally adopted International Conference on Harmonization guidelines, and has similar regulatory standards as Canada if the product can be linked to an equivalent Canadian product through manufacturing company/facility, dosage form, etc. ${ }^{9}$ Similarly, TGA allows that bridging studies:

[...] may be abbreviated if evidence is provided that the product marketed in Australia is sourced from the same manufacturing facility as that used for the reference product. $^{8}$

However, a larger issue is the potential lack of agreement between regulators on the clinical study design. If regulatory agencies cannot agree, then sponsors may be forced to conduct multiple two-arm studies, and depending on the size of the available market, doing so may not be economically feasible for a sponsor. Core studies, especially analytics, represent a fixed cost of biosimilar approval, while region-specific studies represent a variable cost, which the sponsor then weighs against the value of the market within each region. It is always up to the sponsor to make a proposal and then negotiate with the local regulatory authority as to what will be sufficient. Meanwhile, life cycle management approaches taken by reference product sponsors can be expected to evolve.

\section{Application for marketing approval via the stand-alone or biosimilar pathway}

While biosimilar approval pathways are often described as abbreviated, in certain instances, this may be a misnomer. The biosimilars pathway requires a significant investment in state-of-the art analytic studies on many lots of both reference product and biosimilar product. Before a biosimilar even gets to the comparison stage, it must be reverse engineered to match the reference product in a resource-intensive, iterative process.

As mentioned earlier, it is always the sponsor's choice what approval pathway, either a stand-alone biologic pathway or a biosimilars pathway, the product will be submitted to and reviewed through. Sponsors elect the pathway for their product on a case-by-case basis and may choose a different route for the same product in different regions. Examples exist of just this (eg, Teva's filgrastim is a biosimilar in Europe and a stand-alone 
biologic in the US). Sponsors weigh many considerations when making this decision, some of which are outlined in Figure 2.

One major consideration factoring into the pathway decision is the ability of the sponsor to obtain extrapolation between indications for its product. Given the cost of demonstrating biosimilarity, the value of the abbreviated pathway is the reduction in clinical trial data burden. If ultimately, biosimilars sponsors are required to conduct efficacy and safety trials in all/most indications, the value of the biosimilar pathway is greatly diminished.

In Europe, for example, so far all the approved biosimilars have obtained all the indications of the reference product (at the time of the biosimilar's approval) with some extrapolation. In contrast, in Canada, this has not been the case. In the US, the ability of biosimilar sponsors to obtain extrapolation (and what the requirements will look like) is still an open question. If extrapolation becomes too unpredictable, sponsors may elect to use the originator biologic path. In the US, for example, this would allow the product to come to market sooner, enjoy 12 years of regulatory exclusivity (protection from biosimilars), sidestep the need for reverse engineering to high similarity, avoid the as of yet untested and complicated patent provisions in the law, and allow a superior, bio-better copy to enter the market.

\section{Interchangeable biologics and the US market}

Another strategic consideration, specific to the US market, is the possibility of obtaining an interchangeable biologic designation for a product licensed as biosimilar. US law allows FDA to approve a product as an interchangeable biologic if it "can be expected to produce the same clinical result as the reference product in any given patient" and:

for a biological product that is administered more than once to an individual, the risk in terms of safety or diminished efficacy of alternating or switching between use of the biological product and the reference product is not greater than the risk of using the reference product without such alternation or switch. ${ }^{4}$

By law, an interchangeable biologic can be substituted for its reference product at the pharmacy without intervention of the prescribing physician. ${ }^{4}$ Of course, this only applies to products dispensed at the pharmacy (a small fraction of biologics, which otherwise tend to be IV administered by a physician). FDA has yet to clarify the requirements for interchangeability, although the agency has stated that it highly recommends that sponsors use a two-step process for obtaining the interchangeable biologic designation, first gaining approval as a biosimilar and then submitting a supplement with new data to support interchangeability (likely including a clinical switching study). Biosimilar sponsors will again weigh the benefits and costs/risks of this pathway when deciding their regulatory strategy.

\section{Conclusion}

While significant progress has been made in the development, approval, and commercialization of biosimilars in the highly regulated markets, it is not clear whether the regulatory environment is conducive to significant abbreviation in biosimilar

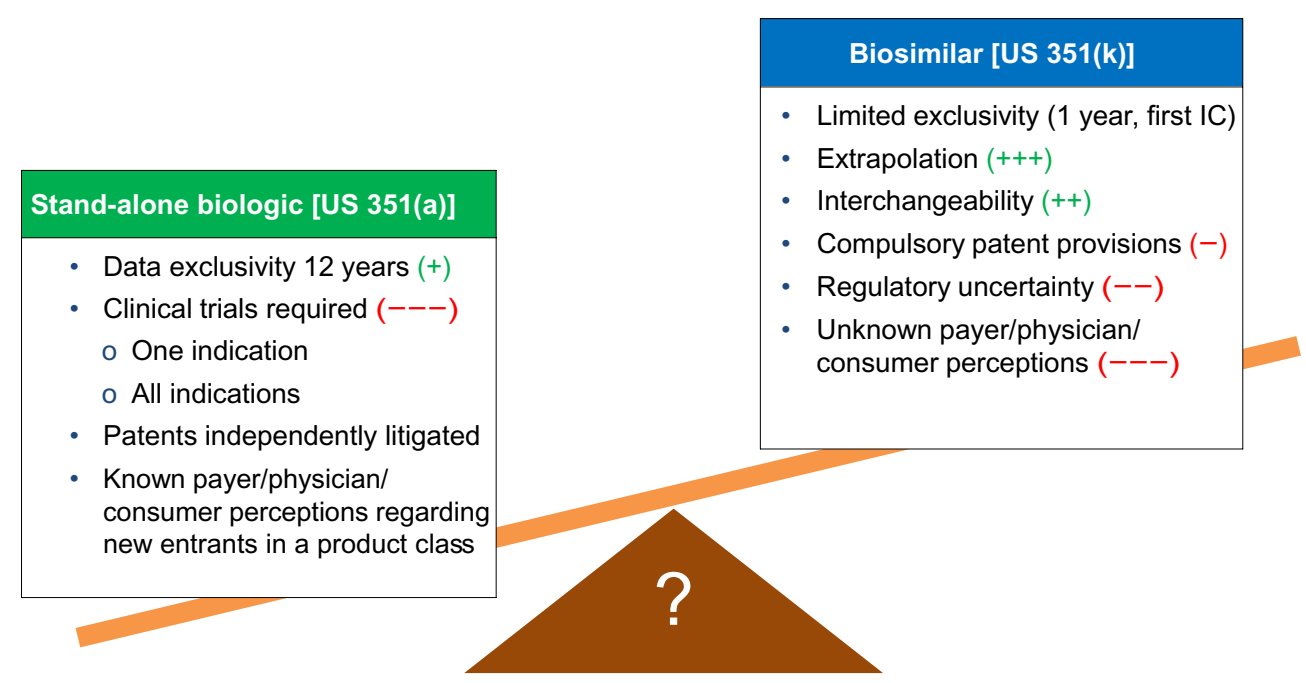

Figure 2 The balance between a stand-alone biologic and a biosimilar.

Notes: Balancing pros and cons for each pathway in the United States, sponsors have to weigh the risks and benefits of each pathway for each product to decide which path will present the greatest potential return on investment in each market. Without extrapolation between indications, the biosimilars pathway has questionable value. Low benefit $(+)$, medium benefit $(++)$, high benefit $(+++)$; low risk $(-)$, medium risk $(--)$, high risk $(---)$. 35 I (a), is the standalone biologic statutory approval pathway in the US. $35 \mathrm{I}(\mathrm{k})$, is the biosimilar and interchangeable biologic statutory approval pathway in the US. 
development. This is despite the extensive experience of regulators with comparability in support of manufacturing changes and therefore with extrapolation and interchangeability for all those biologics likely to be the reference products for biosimilars. Nor is it clear whether global development of a single data package for multiple jurisdictions will be possible in the manner now expected for originator products and also for generic drugs. Nonetheless, with the US as the largest single market now in play and FDA reviewing at least four biosimilar applications, much is expected to be learned in 2015 as to the feasibility of global biosimilar product development. It may take a few more years post-approval to see the commercial sustainability of these products emerge, or not, as clearly biosimilars will behave neither like generics nor originator biologics in the market place, and a third model will need to emerge. Biosimilars and interchangeable biologics offer the opportunity for a competitive market for biologics, but the sustainability of the market will be as crucial as regulatory predictability to their success offering increased access and affordability for patients.

\section{Disclosure}

The author reports no conflicts of interest in this work.

\section{References}

1. EMA Guideline on Similar Biological Medicinal Products, CHMP/437/04, October 30, 2005. Available from: http://www.ema. europa.eu/docs/en_GB/document_library/Scientific_guideline/2009/09/ WC500003517.pdf. Accessed February 12, 2015.

2. WHO Guidelines on evaluation of similar biotherapeutic products (SBPs), adopted October 19-23, 2009. Available from: http://www.who. int/biologicals/areas/biological_therapeutics/BIOTHERAPEUTICS_ FOR_WEB_22APRIL2010.pdf. Accessed February 12, 2015.

3. FDA biosimilar draft guidances Available from: http://www.fda. gov/Drugs/GuidanceComplianceRegulatoryInformation/Guidances/ ucm290967.htm. Accessed February 12, 2015.

4. US Government Publishing Office [homepage on the Internet]. § 262, Regulation of biological products. Available from: http://www.gpo.gov/ fdsys/pkg/USCODE-2010-title42/pdf/USCODE-2010-title42-chap6AsubchapII-partF-subpart1-sec262.pdf. Accessed

5. McCamish M, Pakulski J, Sattler C, Woollett, G. Toward interchangeable biologics. Clin Pharmacol Ther. 2015; doi: 10.1002/cpt.39.

6. International Conference on Harmonisation (ICH) Guideline on Comparability of Biotechnological/Biological Products Subject to Changes in their Manufacturing Process Q5E; November 18, 2004. Available from: http:// www.ich.org/fileadmin/Public_Web_Site/ICH_Products/Guidelines/ Quality/Q5E/Step4/Q5E_Guideline.pdf. Accessed February 12, 2015.

7. PMDA Guideline for the Quality, Safety and Efficacy Assurance of Follow-on Biologics, PFSB/ELD Notification No 0304007, March 4, 2009. Available from: http://www.pmda.go.jp/english/service/pdf/ notifications/PFSB-ELD-0304007.pdf. Accessed February 12, 2015.

8. TGA, Evaluation of biosimilars. Available from: https://www.tga.gov. au/evaluation-biosimilars. Accessed February 12, 2015.

9. Health Canada, Guidance for Sponsors: Information and Submission Requirements for Subsequent Entry Biologics (SEBs), March 5, 2010. Available from: http://hc-sc.gc.ca/dhp-mps/alt_formats/pdf/brgtherap/ applic-demande/guides/seb-pbu/seb-pbu-2010-eng.pdf. Accessed February 12, 2015.
10. Schiestl M, Stangler T, Torella C, Cepeljnik T, Toll H, Grau R. Acceptable changes in quality attributes of glycosylated biopharmaceuticals. Nat Biotech. 2011;29(4):310-312.

11. Schneider CK. Biosimilars in rheumatology: the wind of change. Annals Rheum Dis. 2013;72(3):315-318.

12. EMA Guideline on the Clinical Investigation of the Pharmacokinetics of Therapeutic Proteins, CHMP/EWP/89249/2004, January 24, 2007. Available from: http://www.ema.europa.eu/docs/en_GB/document_ library/Scientific_guideline/2009/09/WC500003029.pdf. Accessed February 12, 2015.

13. EMA Annex: Guidance on Similar Medicinal Products Containing Somatropin, EMEA/CHMP/BMWP/94528/2005, February 22, 2006. Available from: http://www.ema.europa.eu/docs/en_GB/document_ library/Scientific_guideline/2009/09/WC500003956.pdf. Accessed February 12, 2015.

14. Omnitrope ${ }^{\circledR}$ : EPAR-Scientific Discussion. Available from: http://www.ema. europa.eu/docs/en_GB/document_library/EPAR_-_Scientific_Discussion/ human/000607/WC500043692.pdf. Accessed February 12, 2015.

15. EMA Guideline on similar biological medicinal products containing biotechnology-derived proteins as active substance: non-clinical and clinical issues, EMEA/CHMP/BMWP/42832/2005 Rev.1, December 18, 2014. Available from: http://www.ema.europa.eu/docs/en_GB/ document_library/Scientific_guideline/2015/01/WC500180219.pdf. Accessed February 12, 2015.

16. Health Canada Summary basis of decision (SBD) for Omnitrope ${ }^{\circledR}$. Available from: http://www.hc-sc.gc.ca/dhp-mps/alt_formats/pdf/ prodpharma/sbd-smd/phase1-decision/drug-med/sbd_smd_2009_ omnitrope_113380-eng.pdf. Accessed February 12, 2015.

17. FDA Letter of Approval for Omnitrope ${ }^{\circledR}$. Available from: http://www. accessdata.fda.gov/drugsatfda_docs/nda/2006/021426s000_APPROV. pdf. Accessed February 12, 2015.

18. Arato T, Yamaguchi T. Experience of reviewing the follow-on biologics including somatropin and erythropoietin in Japan. Biologicals. 2011;39: 289-292.

19. Biograstim ${ }^{\circledR}$. EPAR-Public Assessment Report. Available from: http:// www.ema.europa.eu/docs/en_GB/document_library/EPAR_-_Public_ assessment_report/human/000826/WC500053904.pdf. Accessed February 12, 2015.

20. Zarzio ${ }^{\circledR}$. EPAR - Public Assessment Report. Available from: http:// www.ema.europa.eu/docs/en_GB/document_library/EPAR_Public_assessment_report/human/000917/WC500046528.pdf. Accessed February 12, 2015.

21. Nivestim ${ }^{\circledR}$. EPAR -Public Assessment Report. Available from: http:// www.ema.europa.eu/docs/en_GB/document_library/EPAR_-_Public_ assessment_report/human/001142/WC500093664.pdf. Accessed February 12, 2015.

22. Grastofil ${ }^{\circledR}$. EPAR -Public Assessment Report. Available from: http:// www.ema.europa.eu/docs/en_GB/document_library/EPAR_-_Public_ assessment_report/human/002150/WC500154066.pdf. Accessed February 12, 2015.

23. EMA Guideline on Similar Medicinal Products Containing Recombinant Granulocyte-Colony Stimulating Factor, EMEA/CHMP/ BMWP/31329/2005. February 22, 2006. Available from: http://www. ema.europa.eu/docs/en_GB/document_library/Scientific_guideline/2009/09/WC500003955.pdf. Accessed February 12, 2015.

24. Ratiograstim ${ }^{\circledR}$. EPAR-Public Assessment Report. Available from: http://www.ema.europa.eu/docs/en_GB/document_library/EPAR_-Public_assessment_report/human/000825/WC500047793.pdf. Accessed February 12, 2015.

25. Tevagrastim ${ }^{\circledR}$. EPAR-Public Assessment Report. Available from: http://www.ema.europa.eu/docs/en_GB/document_library/EPAR_-Public_assessment_report/human/000827/WC500036667.pdf. Accessed February 12, 2015.

26. Filgrastim Hexal ${ }^{\circledR}$. EPAR-Public Assessment Report. Available from: http://www.ema.europa.eu/docs/en_GB/document_library/ EPAR_-_Public_assessment_report/human/000918/WC500022471. pdf. Accessed February 12, 2015. 
27. Accofil ${ }^{\circledR}$. EPAR-Public Assessment Report. Available from: http:// www.ema.europa.eu/docs/en_GB/document_library/EPAR_-_Public_ assessment_report/human/003956/WC500176711.pdf. Accessed February 12, 2015.

28. Nivestim ${ }^{\circledR}$. Australian Public Assessment Report. Available from: https:// www.tga.gov.au/auspar/auspar-filgrastim-0. Accessed February 12, 2015.

29. Tevagrastim ${ }^{\circledR}$. Australian Public Assessment Report. Available from: https://www.tga.gov.au/auspar/auspar-filgrastim. Accessed February 12, 2015.

30. Zarzio ${ }^{\circledR}$. Australian Public Assessment Report. Available from: https:// www.tga.gov.au/auspar/auspar-filgrastim-rbe. Accessed February 12, 2015.

31. Binocrit ${ }^{\circledR}$. EPAR-Scientific Discussion. Available from: http://www. ema.europa.eu/docs/en_GB/document_library/EPAR_-_Scientific_ Discussion/human/000725/WC500053615.pdf. Accessed February 12, 2015.

32. Retacrit ${ }^{\mathbb{R}}$. EPAR-Scientific Discussion. Available from: http://www. ema.europa.eu/docs/en_GB/document_library/EPAR_-_Scientific_ Discussion/human/000872/WC500054374.pdf. Accessed February 12, 2015.

33. EMA Guideline on non-clinical and clinical development of similar biological medicinal products containing recombinant erythropoietins (Revision); 2010. Available from: http:/www.ema.europa.eu/docs/en GB/document_library/Scientific_guideline/2010/04/WC500089474. pdf. Accessed February 12, 2015.

34. Epoetin alfa Hexal ${ }^{\circledR}$. EPAR-Scientific Discussion. Available from: http://www.ema.europa.eu/docs/en_GB/document_library/EPAR_-_ Scientific_Discussion/human/000726/WC500028287.pdf. Accessed February 12, 2015.

35. Abseamed ${ }^{\circledR}$. EPAR-Scientific Discussion. Available from: http://www. ema.europa.eu/docs/en_GB/document_library/EPAR_-_Scientific_ Discussion/human/000727/WC500020666.pdf. Accessed February 12, 2015.

36. Silapo ${ }^{\circledR}$. EPAR-Scientific Discussion. Available from: http://www. ema.europa.eu/docs/en_GB/document_library/EPAR_-_Scientific_ Discussion/human/000760/WC500050914.pdf. Accessed February 12, 2015.

37. Binocrit ${ }^{\circledR}-\mathrm{H}-\mathrm{C}-725-\mathrm{II}-06$. EPAR-Assessment Report-Variation. Available from: http://www.ema.europa.eu/docs/en_GB/document_ library/EPAR_-_Assessment_Report_-_Variation/human/000725/ WC500053679.pdf. Accessed February 12, 2015.

38. Epoetin alfa Hexal ${ }^{\mathbb{B}}-\mathrm{H}-\mathrm{C}-726-\mathrm{X}-10$. EPAR-Assessment Report-Variation. Available from: http:/www.ema.europa.eu/docs/en_GB/document_ library/EPAR_-_Assessment_Report_-_Variation/human/000726/ WC500028283.pdf. Accessed February 12, 2015.

39. Abseamed ${ }^{\mathbb{E}}-\mathrm{H}-\mathrm{C}-727-\mathrm{II}-06$. EPAR-Assessment Report-Variation. Available from: http://www.ema.europa.eu/docs/en_GB/document_ library/EPAR_-_Assessment_Report_-_Variation/human/000727/ WC500020660.pdf. Accessed February 12, 2015.
40. Retacrit ${ }^{\mathbb{R}}$. EPAR-Procedural steps taken and scientific information after authorization. Available from: http://www.ema.europa.eu/docs/ en GB/document_library/EPAR - Procedural_steps taken and scientific_information_after_authorisation/human/000872/WC500054376. pdf. Accessed February 12, 2015.

41. Silpo ${ }^{\circledR}$. EPAR-Procedural steps taken and scientific information after authorization. Available from: http://www.ema.europa.eu/docs/en_GB/ document_library/EPAR_-_Procedural_steps_taken_and_scientific_ information_after_authorisation/human/000760/WC500050916.pdf. Accessed February 12, 2015.

42. Retacrit ${ }^{\circledR}-\mathrm{H}-\mathrm{C}-872-\mathrm{II}-36$. EPAR-Assessment Report-Variation. Available from: http://www.ema.europa.eu/docs/en_GB/document_ library/EPAR_-_Assessment_Report_-_Variation/human/000872/ WC500116652.pdf. Accessed February 12, 2015.

43. Epoetin Lambda. Australian Pharmaceutical Benefits Scheme, Public Summary Document. Available from: http:/www.pbs.gov.au/industry/ listing/elements/pbac-meetings/psd/2010-07/Epoetin_lambda_ NOVICRIT_Novartis2.pdf. Accessed February 12, 2015.

44. Korean approval of Celltrion's Infliximab ${ }^{\circledR}$. Available from: http://www. celltrion.com/en/COMPANY/company02.asp?menu_num=2. Accessed February 12, 2015.

45. Remsima ${ }^{\circledR}$. EPAR-Public Assessment Report. Available from: http:// www.ema.europa.eu/docs/en_GB/document_library/EPAR_-_Public_ assessment_report/human/002576/WC500151486.pdf. Accessed February 12, 2015.

46. Inflectra ${ }^{\circledR}$. EPAR-Public Assessment Report. Available from: http:// www.ema.europa.eu/docs/en_GB/document_library/EPAR_-_Public_ assessment_report/human/002778/WC500151490.pdf. Accessed February 12, 2015.

47. EMA Guideline on similar biological medicinal products containing monoclonal antibodies - non-clinical and clinical issues; 2012. Available from: http://www.ema.europa.eu/docs/en_GB/document_library/ Scientific_guideline/2012/06/WC500128686.pdf. Accessed February $12,2015$.

48. Remsima ${ }^{\circledR}$. Health Canada Summary Basis of Decision. Available from: http://www.hc-sc.gc.ca/dhp-mps/prodpharma/sbd-smd/drugmed/sbd_smd_2014_remsima_160195-eng.php. Accessed February 12,2015 .

49. Inflectra ${ }^{\circledR}$. Health Canada Summary Basis of Decision. Available from: http://www.hc-sc.gc.ca/dhp-mps/prodpharma/sbd-smd/drug-med/sbd smd_2014_inflectra_159493-eng.php. Accessed February 12, 2015.

50. Japanese approval of Remisma ${ }^{\circledR}$. Available from: http://www.pmda. go.jp/english/service/pdf/list/NewdrugsFY2014.pdf. Accessed February 12, 2015.
Biosimilars

\section{Publish your work in this journal}

Biosimilars is an international, peer-reviewed, open access journal focusing on the manufacture, development and medicinal use of biopharmaceutical compounds considered similar to an innovator agent. Specific topics covered in the journal include: Regulatory issues and pathways; manufacturing processes; chemical composition and

\section{Dovepress}

structure; quality and purity; patent issues; bioequivalence and interchangeability; clinical efficacy data; patient perspectives. The manuscript management system is completely online and includes a very quick and fair peer-review system. Visit http://www.dovepress.com/ testimonials.php to read real quotes from published authors. 